\title{
A new genus and new species of freshwater crab (Potamoidea, Potamidae) from Socotra Island, Yemen
}

\author{
NEIL CUMBERLIDGE $\dagger$ and WOLFGANG WRANIK $\ddagger$ \\ $\dagger$ Department of Biology, Northern Michigan University, Marquette, \\ MI 49855, USA, and $\$$ Fachbereich Biologie Universitaet Rostock, \\ Freiligrathstrasse 7/8, 18051 Rostock, Germany
}

(Accepted 4 July 2000)

\begin{abstract}
A new species of freshwater crab from the semi-arid highlands of Socotra Island, Yemen, is described. The unusual combination of characters of these specimens warrants the establishment of a new genus (Socotra) to accommodate the new species. The new taxon is compared to Potamon socotrensis, the other species of freshwater crab occurring in Socotra. The two species of freshwater crabs on Socotra (Potamon and Socotra) are both endemic and both show affinities with the Potamidae, a freshwater crab family with a wide distributional range that includes north-west Africa, south-east Europe, the Middle East, the Himalayas, South-East Asia and China. Perhaps surprisingly, given the close proximity of the island to the coast of Africa, the Socotran freshwater crabs were not found to be closely related to the freshwater crab families found in East Africa (Potamonautidae and Deckeniidae).
\end{abstract}

Keywords: Crustacea, Brachyura, freshwater crab, taxonomy, Potamoidea, Potamidae, Socotra.

\section{Introduction}

The present report was prompted by the acquisition of unusual specimens of freshwater crabs from Socotra by one of the authors (W.W.), while carrying out fieldwork on the island. Socotra is located in the Indian Ocean some $250 \mathrm{~km}$ east of Somalia in the horn of Africa, but is politically part of the Republic of Yemen in the Arabian Peninsula to the north. There is a high percentage of endemism of the flora and fauna of Socotra in general, and until the present work the faunal list included only one species of potamid freshwater crab, Potamon socotrensis (Hilgendorf, 1883). This species is endemic to the island and is widespread and locally common. Potamon socotrensis is primarily aquatic, occurring in streams and rivers, and almost anywhere a reliable supply of freshwater is found.

We report here on the discovery of a second endemic species of freshwater crab from Socotra. The new species is secretive, but it is considerably larger than $P$. socotrensis, and is apparently restricted to a semi-arid mountainous inland locality, far away from permanent freshwater sources and far away from the coast. The new 
specimens, reported on here as Socotra pseudocardisoma n. gen. n. sp., consist of two adult males and one adult female. The new species is distinctly different from both $P$. socotrensis and from $P$. fluviatile Savigny, 1816 from Italy in a number of important taxonomic characters of the mandible, gonopods, carapace, sternum, epistome and third maxilliped. These differences are sufficient to warrant the recognition of a new genus, which we have assigned here tentatively to the family Potamidae.

The Socotra archipelago comprises a chain of four islands: Socotra, Abd al Kuri, Samha and Darsa. These islands are all part of the Republic of Yemen and are situated in the north-western Indian Ocean $\left(12^{\circ} 06^{\prime}-12^{\circ} 42^{\prime} \mathrm{N} ; 52^{\circ} 03^{\prime}-54^{\circ} 32^{\prime} \mathrm{E}\right.$, figure 5). The islands are separated from one another and from Africa by relatively shallow seas and from the Arabian Peninsula to the north by a deep trench. Socotra is the largest island of the group, about $120 \mathrm{~km}$ long by $40 \mathrm{~km}$ wide, with an area of $3625 \mathrm{~km}$ (figure 5). Socotra lies approximately $250 \mathrm{~km}$ to the east of Somalia in the horn of Africa, and about $345 \mathrm{~km}$ south of the Ras Fartak, the nearest point on the southern coast of the Arabian Peninsula. The island is composed of a basement complex of Pre-Cambrian igneous and metamorphic rocks, overlain by younger sedimentary rocks (mainly limestone and sandstone). Topographically Socotra can be divided into three main zones. These are: (1) a fringing lowland coastal plain of variable width, (2) a limestone plateau (between 300 and $700 \mathrm{~m}$ elevation) that extends over most of the island, and (3) the granitic Haghir mountains in the centre of the island which reach a height of up to $1519 \mathrm{~m}$.

The climate of the Socotra is dominated by seasonal Indian Ocean monsoons: a dry and stormy south-west summer monsoon (from April until October) and a wetter north-east winter monsoon (from November to March). Socotra has a mean annual temperature range from 28 to $37^{\circ} \mathrm{C}$, and a mean annual rainfall range from 130 to $170 \mathrm{~mm}$. In general, the vegetation of Socotra is sparse, and tends to be dominated by xeromorphic plants adapted to a semi-arid climate, but more luxuriant vegetation is found in sheltered valleys and on some mountain slopes (Kingdon, 1989; Mies and Zimmer, 1993; Davis et al., 1994; Mies et al., 1995; Alexander and Miller, 1996).

\section{Abbreviations}

$\mathrm{NHML}=$ The Natural History Museum, London, UK; $\mathrm{NMU}=$ Northern Michigan University, Marquette, MI, USA; UR $=$ Universität Rostock, Rostock, Germany. $\mathrm{CW}=$ carapace at the widest point; $\mathrm{cl}=$ carapace length measured along the median line, from the anterior to the posterior margin; $\mathrm{ch}=$ carapace height, the maximum height of the cephalothorax; $f w=$ front width, the width of the front measured along the anterior margin; $\mathrm{sw}=$ sternum width measured across the widest point; $s=$ thoracic sternite; $e=$ episternite; $s 4 / s 5, s 5 / s 6, s 6 / s 7, s 7 / s 8=$ sternal sutures between adjacent sternites; s4/e4, s5/e5, s6/e6, s7/e7=episternal sutures between adjacent sternites and episternites; al to a6=abdominal segments 1 to $6 ; \mathrm{Pl}$ to P5 $=$ pereiopods 1 to $5 ; \mathrm{m}=$ male; $\mathrm{f}=$ female .

\section{Systematic account}

Socotra n. gen.

Type species. Socotra pseudocardisoma n. sp., by monotypy.

Diagnosis. Cephalothorax heart-shaped $(\mathrm{cw}>\mathrm{cl})$ : highly arched $(\mathrm{ch} / \mathrm{fw} 1.9)$, very 
wide (cw/fw 5.3), very long (cl/fw 3.6); front very narrow (fw/cw 0.2 ). Postfrontal crest low, faint, complete, ends curving forward to meet anterolateral margins at epibranchial teeth; mid-groove between epigastric crests long, flat, wide, forked at posterior end. Exorbital tooth small, low, blunt; epibranchial tooth reduced, almost undetectable; anterolateral margin between exorbital, epibranchial teeth extremely short, lacking intermediate tooth; anterolateral margin posterior to epibranchial tooth forming smooth raised rim. Front sharply deflexed, meeting inferior margins of antennulular fossae so that antennules almost completely enclosed within fossae. Exopod of third maxilliped distinctly widened at midpoint, base; tip narrow (i.e. not long columnar with parallel sides). Third sternal sulcus (s3/s4) reduced to two short notches at lateral edges of sternum; anterior margin of sterno-abdominal cavity almost reaching s3/s4 junction. Episternal sulci s4/e4 to s7/e7 not visible. Gonopod 1 long, extending anteriorly as far as $s 4 / s 5$. Terminal article of gonopod 1 relatively long (about one-third as long as subterminal segment).

Distribution. Socotra is known only from the type locality (figure 5). Unverified local reports of its occurrence from other localities (e.g. Homhil) have been treated with caution, because local people use one word ('hanchio') to describe all crabs, regardless of species.

\section{Taxonomic remarks}

The generic assignment of the new taxon is problematic because Potamon sensu lato represents a large heterogenous group of crabs, with a large number of species with a wide distribution (Pretzmann, 1962, 1963a, 1963b, 1966a, 1966b, 1976, 1983; Bott, 1965, 1970; Ng, 1988; Ng and Naiyanetr, 1993). Bott $(1965,1970)$ included in the genus Potamon only those species with a gonopod 1 with a cylindrical terminal article, and whose subterminal segment has a clearly visible groove for gonopod 2 on the ventral face. However, $\mathrm{Ng}$ and Naiyanetr (1993) were of the opinion that the species referred to Potamon should include only those potamids with a welldeveloped flagellum on the exopod of the third maxilliped. Socotra does not fit well with either of these definitions of the genus.

The area of interest in the present study that is closest to Socotra (north-west Africa, south-east Europe, the Middle East, the Himalayas and northern India) includes two potamid genera: Potamon and Potamiscus (Pretzmann, 1962, 1963a, 1963b, 1966a, 1966b, 1976, 1983; Bott, 1970). The following characters argue against the inclusion of the new species from Socotra in either Potamon or Potamiscus (sensu Bott, 1970; Ng, 1988): the exopod of the third maxilliped of Socotra is distinctly widened in the middle, the lateral epistome of Socotra is distinctly raised above the epistomial tooth; and the anterior end of the sterno-abdominal cavity on s4 of Socotra extends forward so that it almost reaches s3. Furthermore, the new specimens are not close to any other described genus in the family Potamidae (see Bott, 1970; $\mathrm{Ng}, 1988$; $\mathrm{Ng}$ and Naiyanetr, 1993); they are therefore assigned here to a new genus, Socotra.

Socotra pseudocardisoma $\mathrm{n}$. $\mathrm{sp}$.

(figures 1-6)

Material examined. Holotype: NHML reg. 1999: adult male (cw 77.2, cl 52.4, ch 28.3, fw 14.7 mm). Paratype: UR reg. 1999: adult male (cw 90.5, cl 59.0, ch 33.5, fw 

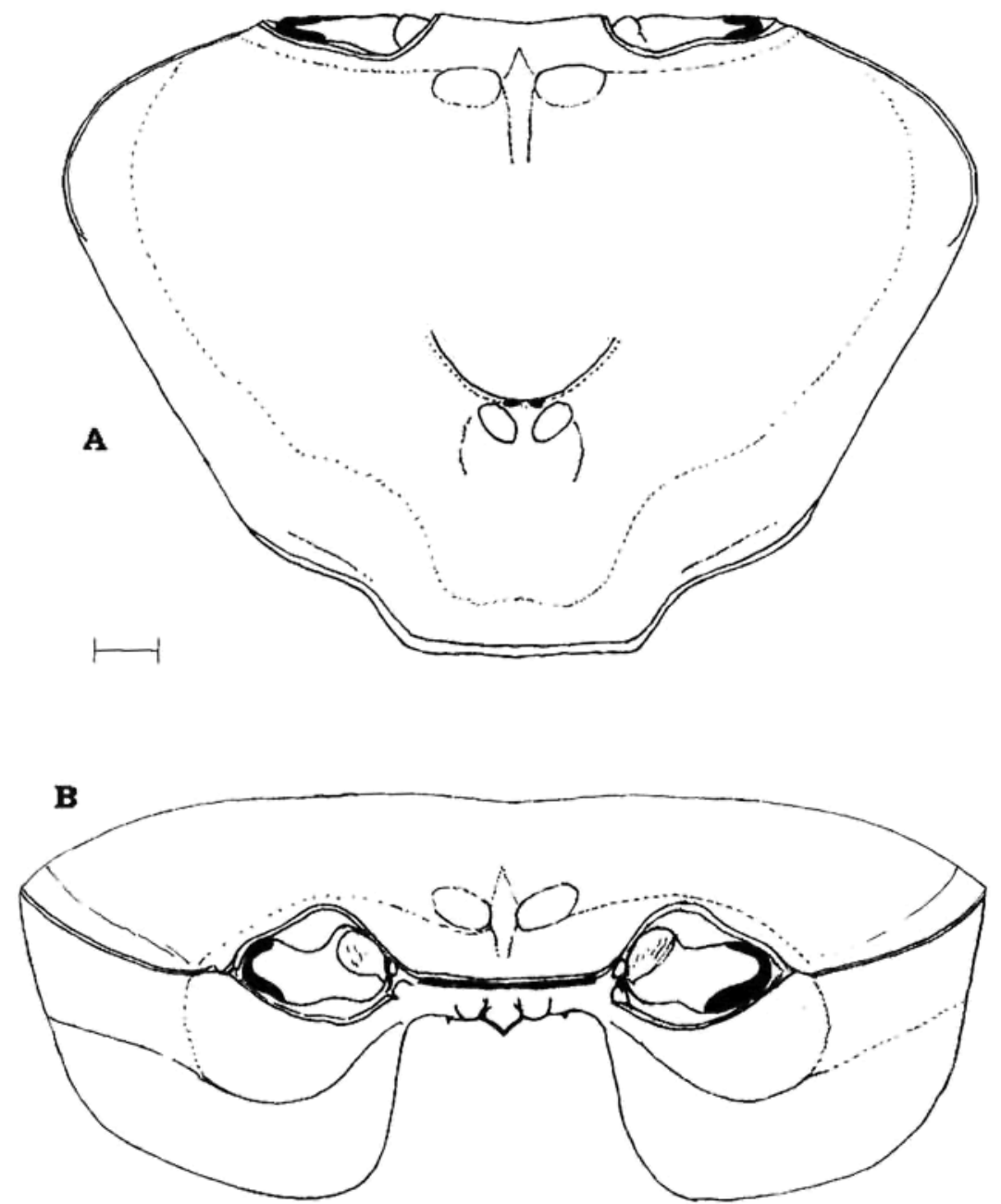

FIG. 1. Socotra pseudocardisoma new species. from Socotra, male, holotype, carapace width $=77.2 \mathrm{~mm}$. (A) Cephalothorax, dorsal aspect; (B) cephalothorax, frontal aspect. Scale bar: $5.0 \mathrm{~mm}$.

$15.5 \mathrm{~mm})$, from Diksam $\left(12^{\circ} 29^{\prime} \mathrm{N}, 53^{\circ} 59^{\prime} \mathrm{E}\right), 700 \mathrm{~m}$, coll. W. Wranik, 4 October 1998. Paratype: NMU reg. 1999: adult female (cw 77.2, cl 52.4, ch 28.3, fw $14.7 \mathrm{~mm}$ ) from Diksam, $700 \mathrm{~m}$, coll. W. Wranik, 5 November 1997. Eleven other specimens of $S$. pseudocardisoma are held at UR.

Diagnosis. Cephalothorax heart-shaped $(\mathrm{cw}>\mathrm{cl})$ : highly arched $(\mathrm{ch} / \mathrm{fw} 1.9)$, very wide (cw/fw 5.3), very long (cl/fw 3.6); front very narrow (fw/cw 0.2 ). Postfrontal crest low, faint, complete, ends curving forward to meet anterolateral margins at epibranchial teeth; mid-groove between epigastric crests long, flat, wide, forked at posterior end. Exorbital tooth small, low, blunt; epibranchial tooth reduced, almost undetectable, forming part of rim of anterolateral margin; anterolateral margin between exorbital, epibranchial teeth extremely short, lacking intermediate tooth; anterolateral margin posterior to epibranchial tooth forming a smooth raised rim. Front sharply deflexed, meeting inferior margins of antennulular fossae so that 

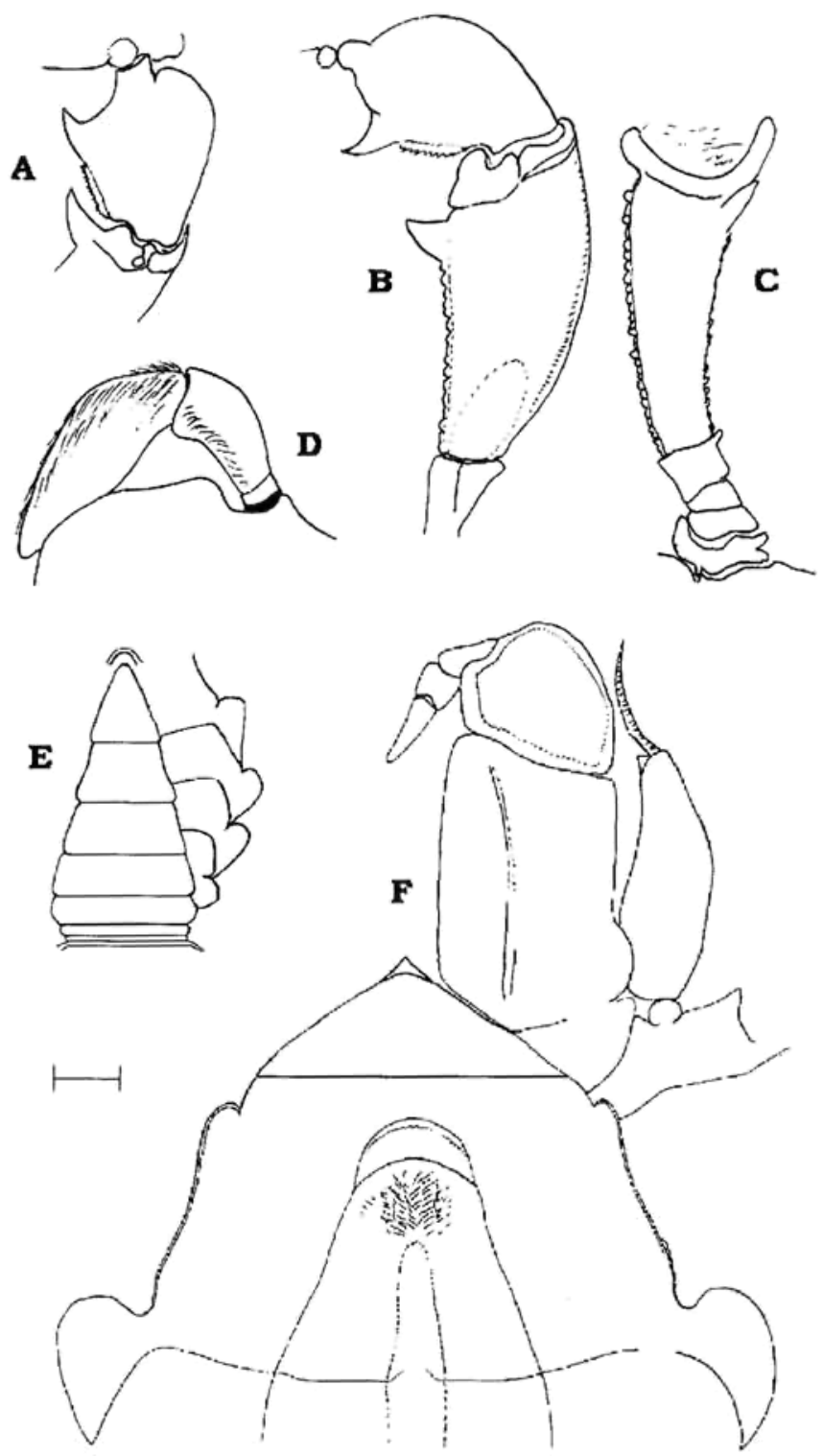

Fig. 2. Socotra pseudocardisoma new species, from Socotra, male, holotype, carapace width $=77.2 \mathrm{~mm}$. (A) Carpus of right cheliped, superior view; (B) carpus and merus of right cheliped, superior view; (C) merus of right cheliped inferior view; (D) left mandible showing details of palp; (E) abdomen and part of sternum; (F) left third maxilliped showing details of the exopod, and anterior sternum. Scale bar: $6.0 \mathrm{~mm}(\mathrm{~A}-\mathrm{C}), 1.2 \mathrm{~mm}(\mathrm{D}), 10.0 \mathrm{~mm}(\mathrm{E}), 2.6 \mathrm{~mm}(\mathrm{~F})$.

antennules almost completely enclosed within fossae. Mandibular palp threesegmented, terminal segment single, undivided. Exopod of third maxilliped distinctly widened at midpoint, base, tip narrow (i.e. not long, columnar with parallel sides). Third sternal sulcus $(\mathrm{s} 3 / \mathrm{s} 4)$ reduced to two short notches at lateral edges of sternum; anterior margin of sterno-abdominal cavity almost reaching $s 3 / s 4$ junction. 

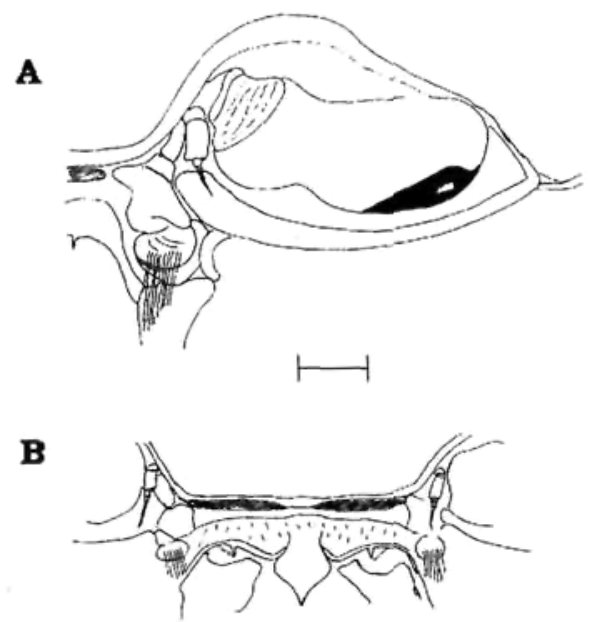

FIG. 3. Socotra pseudocardisoma new species, from Socotra, male, type, carapace width= $77.2 \mathrm{~mm}$. (A) Details of left orbital region, frontal view; (B) details of frontal region, frontal view. Scale bar: $2.5 \mathrm{~mm}$.

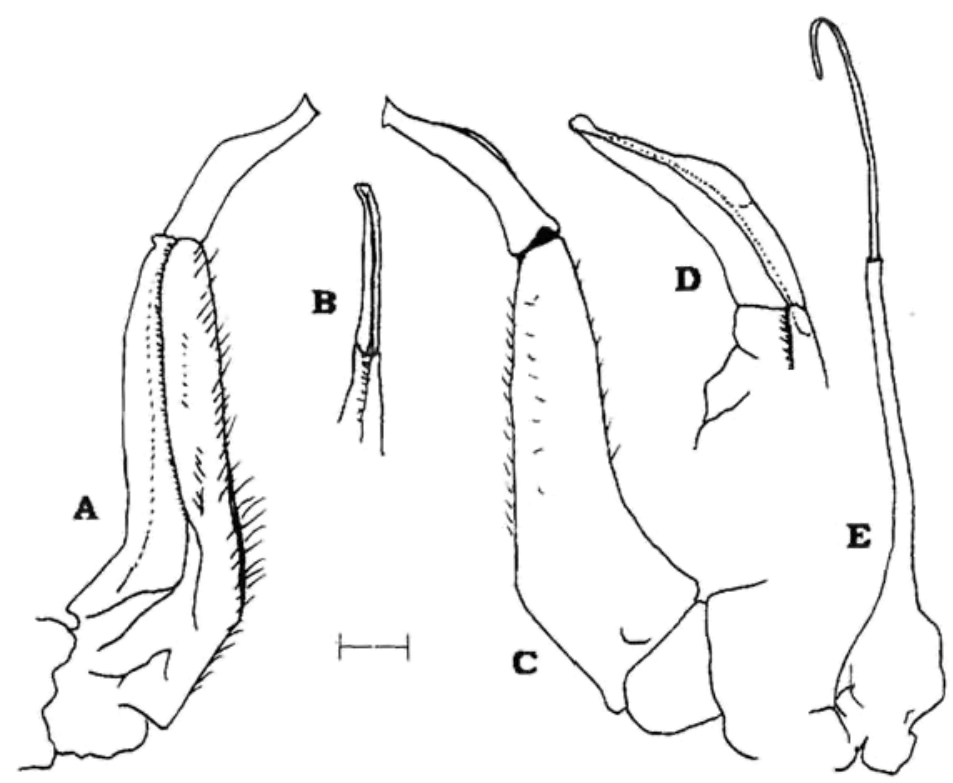

FIG. 4. Socotra pseudocardisoma new species, from Socotra, male, type, carapace width $=$ $77.2 \mathrm{~mm}$. (A) Right gonopod 1, ventral aspect; (B) right gonopod 1, dorsal aspect; (C) right gonopod 1, dorsal aspect; (D) right gonopod 1, superior view, showing groove; (E) right gonopod 2, ventral aspect. Scale bar: $2.5 \mathrm{~mm}(\mathrm{~A}-\mathrm{C}, \mathrm{E}), 1.6 \mathrm{~mm}(\mathrm{D})$.

Episternal sulci $s 4 / \mathrm{e} 4$ to $\mathrm{s} 7 / \mathrm{e} 7$ not visible. Gonopod 1 long, extending anteriorly as far as $s 4 / s 5$. Terminal article of gonopod 1 relatively long (about one-third as long as subterminal segment), terminal article of gonopod 2 long, flagellum-like (almost as long as subterminal segment of gonopod 2).

Description. Following description based on male holotype (NHML reg. 1999: adult male, cw $77.2 \mathrm{~mm})$. Cephalothorax heart-shaped $(\mathrm{cw}>\mathrm{cl})$ : highly arched $(\mathrm{ch} / \mathrm{fw}$ 


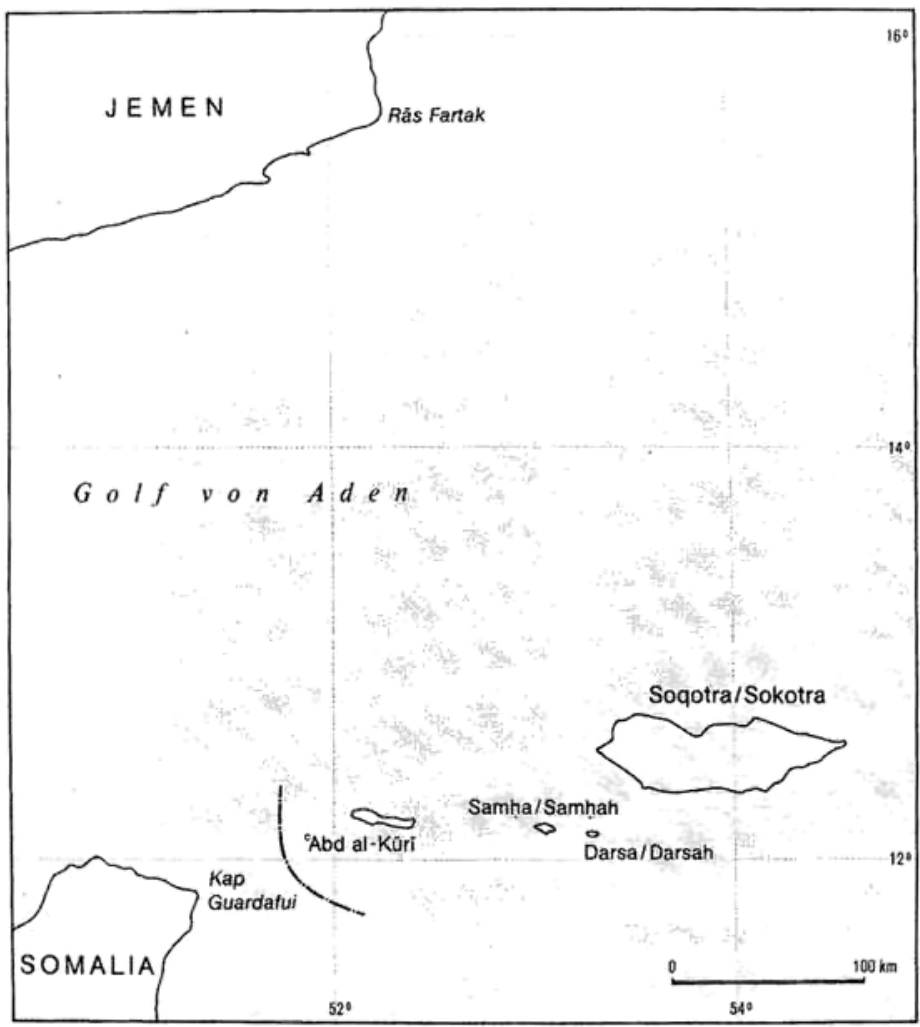

(a)

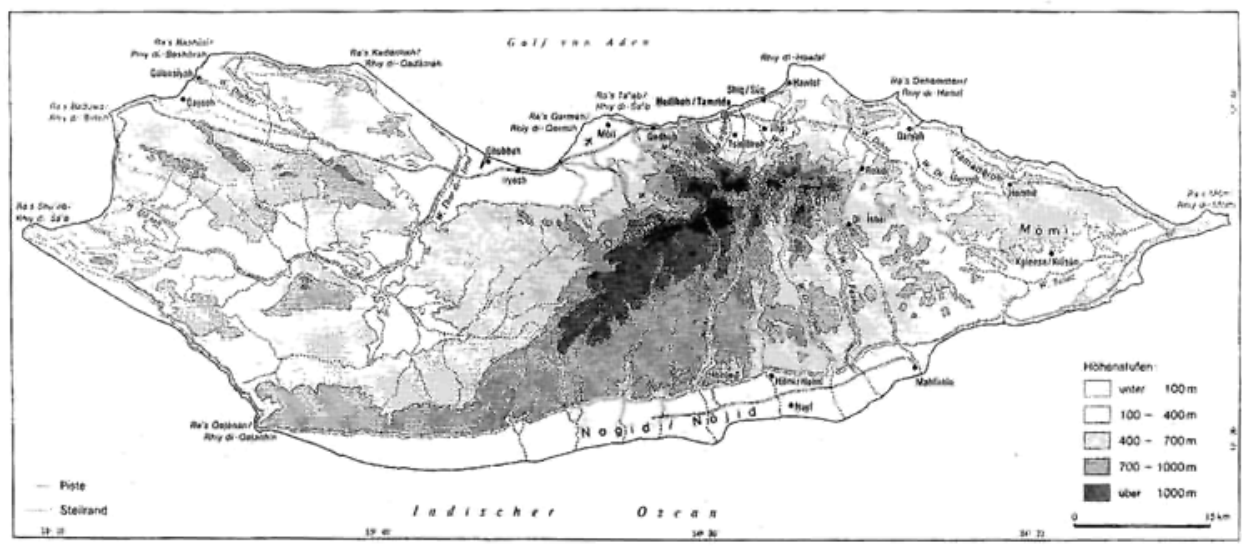

(b)

Fig. 5. (a) Sketch map showing the Socotra Archipelago (source: Kopp, in Wranik, 1999); (b) map of Socotra showing highland area where Socotra pseudocardisoma new species was collected $\left(12^{\circ} 27^{\prime} \mathrm{N}, 53^{\circ} 59^{\prime} \mathrm{E}\right)$.

1.9), very wide (cw/fw 5.3), very long (cl/fw 3.6); front very narrow (fw/cw 0.2 ). Dorsal surface of carapace texture smooth; semicircular, urogastric grooves deep, cervical grooves deep, short; transverse cardiac grooves faint; branchial grooves not visible. Postfrontal crest low, faint, complete, ends curving forward to meet 


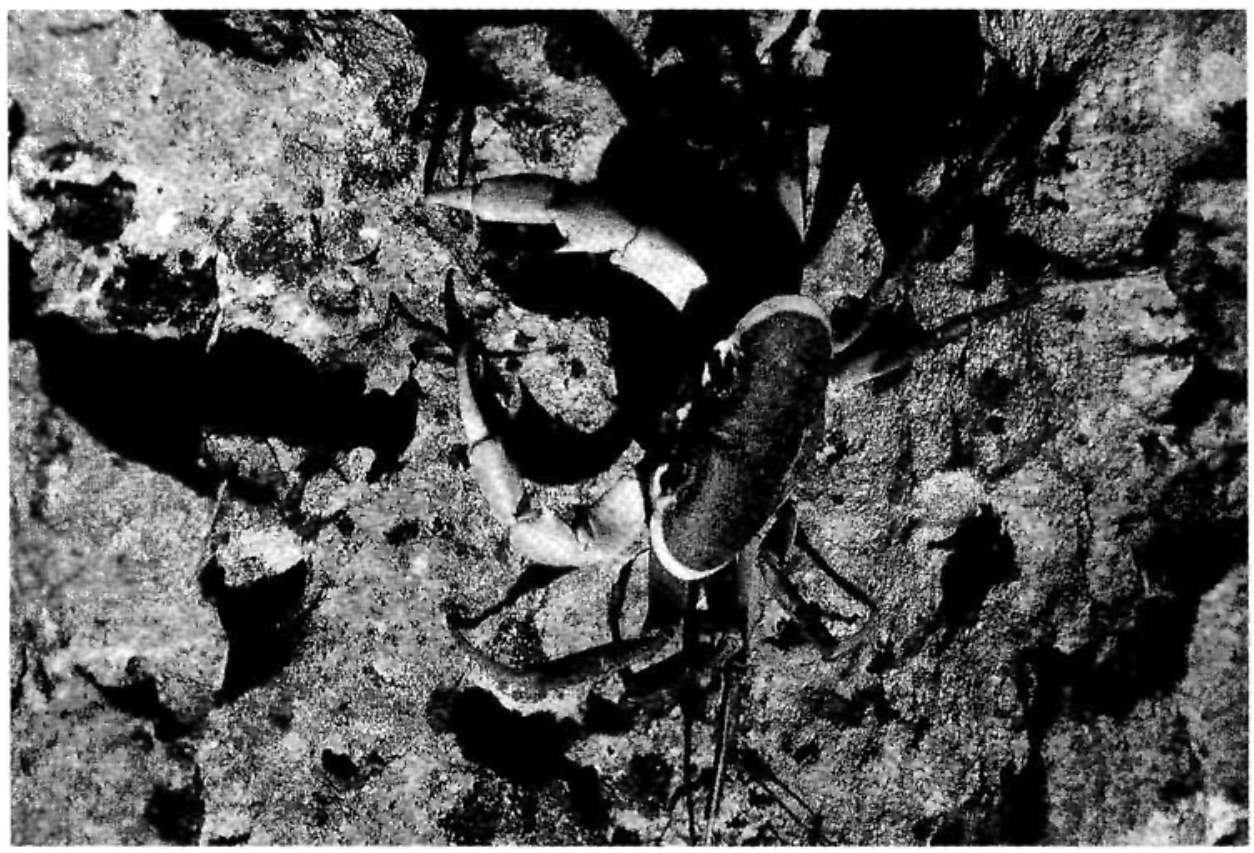

FIG. 6. Male specimen of Socotra pseudocardisoma climbing on a rock in the limestone plateau type locality of Socotra.

anterolateral margins at epibranchial teeth; mid-groove between epigastric crests long, flat, wide, forked at posterior end; mid-groove extending anteriorly for short distance on to frontal region. Exorbital tooth small, low, blunt; epibranchial tooth reduced, almost undetectable, forming part of rim of anterolateral margin; anterolateral margin between exorbital, epibranchial teeth extremely short, lacking intermediate tooth; anterolateral margin posterior to epibranchial tooth forming a smooth raised rim, posterior end curving inward.

Front sharply deflexed, meeting inferior margins of antennulular fossae so that antennules almost completely enclosed within fossae. Lateral parts of epistome forming upper roof of efferent channels overlapping large, triangular, horizontal epistomial tooth. Margins of lateral epistome, epistomial tooth smooth, distinct endostomial ridge visible on lateral epistome marking medial boundary of efferent channel formed where broadened endopod of first maxilliped meets endostome. Mandibular palp three-segmented terminal segment single, undivided. Third maxillipeds filling oral field, medial margins of ischia, meri vertical, meeting along entire length; ischium with deep vertical sulcus; exopod of third maxilliped distinctly widened at midpoint, base, tip narrow; exopod flagellum reduced, measuring only half length of exopod. First sternal sulcus (s1/s2) short, distinct; second sulcus (s2/s3) deep, running horizontally across sternum; third sternal sulcus ( $33 / \mathrm{s} 4)$ reduced to two short notches at lateral edges of sternum, in line with basal segment of third maxillipeds; anterior margin of sterno-abdominal cavity almost reaching s3/s4 junction; episternal sulci (s4/e4 to s7/e 7) not visible.

Dactylus of right cheliped narrow (one-quarter height of palm), upper margin smooth; dactylus slightly arched, enclosing long narrow interspace; finger of propodus slim (one-quarter height of palm). Lower margin of propodus indented. Both 
fingers with series of small pointed teeth, interspersed with several bigger teeth. Propodus of cheliped with conspicuous rounded boss at articulation point with carpus of pereiopod 1; carpus with raised flat process at this junction. Medial, lateral inferior margins of merus lined by small distinct teeth; single large pointed distal meral tooth on medial margin; superior margin of merus slightly granular. First carpal tooth of cheliped large, slender, pointed, second carpal tooth small pointed granule, on raised ridge with similar granules. Walking legs (pereiopods 2-5) long, slender; P3 longest, P5 shortest; dactyli of P2-P5 with four distinct rows of short corneous spines; anterior, posterior margins of propodi of P2-P5 smooth.

Male abdomen (a3-a6, plus telson) triangular; telson triangular with almost straight sides directed inward. Gonopod 1 long, reaching sternal groove s4/s5; terminal article relatively long (about one-third as long as subterminal segment); terminal article initially straight, curving sharply outward at halfway point, then curving sharply upward, tapering to broad tip; longitudinal groove visible only on dorsal side; wide dorsal membrane between last two parts; lateral fold of terminal article of gonopod 1 low, equal to medial fold. Gonopod 2 as long as gonopod 1; terminal article of gonopod 2 long, flagellum-like (almost as long as subterminal segment of gonopod 2) basal half straight, distal half either straight or folding back on itself, forming a hook-shape.

Size. The adult size range is up to $\mathrm{cw} 90.5 \mathrm{~mm}$.

Type locality. Diksam, altitude $700 \mathrm{~m}$, limestone plateau $660-740 \mathrm{~m}$.

Distribution. The species is known only from the type locality (figures 5,6).

Colour. In living specimens the dorsal surface of the carapace is dark purple with a broad light brown margin (most males) or brown with a broad yellowish margin (females). In some male specimens the dark surface coloration of the carapace continues over to the pterygostomium of the carapace sidewall. The walking legs (pereiopods P2-P5) are mainly yellowish, except for the ends of the merus, carpus and propodus, which have dark patches.

Ecology. The Haghir massif receives Socotra's highest rainfall totals, and as a consequence the central highlands are frequently shrouded in clouds and heavy mists. Additional sources of water at these higher altitudes include permanent springs and the mist and dew. The Haghir massif forms the most important watershed on the island and this gives rise to numerous watercourses that run to the north and south of these highlands. The upper reaches of the streams running down the northern slopes tend to flow year round, but at the lower elevations these streams become sporadic and flow freely only after rain.

The following field observations of the new taxon were made. Socotra pseudocardisoma is a semi-arid zone crab with terrestrial habits whose behavioural pattern is influenced by seasonal changes. The type locality is in a part of the island where limestone is dominant, and where climatic erosion of the calcareous substratum has produced sinks, underground streams, caverns, hollows and crevices. These temporary aquatic freshwater habitats are located far from conventional freshwater sources (rivers, streams and lakes) and are fed mainly by rainwater. It is possible that there are year-round, more permanent, water deposits deep below the surface, which could also be accessed by these crabs.

Socotra pseudocardisoma lives in crevices, and crabs are not easy to find, because they spend most of the daylight hours concealed from view. Crabs appear only occasionally on the surface, and startled crabs quickly retreat back into the crevice system. These animals can move rapidly on the ground, and can climb agilely and 
rapidly up and down rock surfaces. During the night, crabs leave their resting-places and wander on the surface in search of food. We are unsure of the natural diet of $S$. pseudocardisoma in its natural habitat, but specimens kept in captivity ate plant material and dead animal material.

There are distinct seasonal differences in the behaviour patterns of $S$. pseudocardisoma. Crabs were observed to be active only in October and November, and it is thought likely that they are active on the surface mainly during the wet season (November to March). It is possible that crabs mostly remain in their underground retreats during the drier times of the year (April to October). People that live on the limestone plateau near to the type locality, and who occasionally use these crabs as food, also report a similar seasonal pattern of wet season activity, and dry season disappearance.

We are able to report only basic information on the reproduction and life cycle of this species. It would appear that the production of eggs and release of hatchling crabs is timed to coincide with the wettest part of the year, when presumably plant and animal populations on Socotra are at their maxima. Five free-living juvenile crabs (cw 26-27 mm) already released from the maternal abdominal brood pouch were caught by one of the authors (W. W.) in summer 1998. Indeed, juvenile crabs are regularly sighted by local people during the late summer and early autumn when the monthly rainfall totals are at their highest. In captivity, mating was observed between a hard-shelled female and a hard-shelled male who remained in the copulatory position and/or a postmating embrace for about one day, before resuming normal behaviour. The sperm was presumably stored in the spermatheca of the female for later use in the fertilization of the eggs when they are eventually laid.

\section{Taxonomic remarks}

The proximity of Socotra to the continents of Africa and Asia is interesting because each landmass supports a distinctly different freshwater crab fauna at the family level (Bott, 1970). The question arises as to whether the closest relatives of the Socotran freshwater crabs are to be found in Africa or in the Middle East, and with this, what is their proper family assignment. Old World freshwater crabs are presently assigned to two superfamilies, the Potamoidea (for the Potamidae, Potamonautidae and Deckeniidae) and the Gecarcinucoidea (for the Gecarcinucidae and Parathelphusidae) (Bott, 1970; Ng, 1988; Ng et al., 1995; Cumberlidge, 1999). The Potamonautidae, Platythelphusidae and Deckeniidae are all exclusively African. The Potamidae is a large and widespread family with numerous genera in northwest Africa, south-east Europe, the Middle East, the Himalayas, India, South-East Asia, Indo-China, China, Indonesia and the Philippines (see Bott, 1965, 1970; Ng, 1988; Ng and Dudgeon, 1991; Ng and Naiyanetr, 1993; Dai et al., 1995; Dai, 1997, 1999; Dai and Türkay, 1997). The gecarcinucids are mainly an Asian group with representatives in India and South-East Asia, and possibly the Seychelles and Madagascar (Bott, 1965, 1970; Ng et al., 1995; Cumberlidge, 1999).

The Potamonautidae and Deckeniidae are distinguished from the Potamidae by the form of the mandibular palp: it is two-segmented in the potamonautids and deckeniids and three-segmented in the potamids (Bott, 1970; Ng, 1988; Cumberlidge, 1999). The three-segmented mandibular palp of S. pseudocardisoma implies affinities with the Eurasian potamids, rather than with the families of African freshwater crabs. It should be noted that the Platythelphusidae of Lake Tanganyika have a three-segmented mandibular palp (Cumberlidge, 1999), but these unique lake crabs 
are easily distinguishable from Socotra in a number of important characters (Cumberlidge et al., 1999), and a close relationship between these taxa is considered here to be unlikely. The three-segmented mandibular palp of $S$. pseudocardisoma also rules out any close relationship with the Asian gecarcinucoids, which are characterized by a two-segmented mandibular palp with a bilobed terminal segment (Bott, 1970; Ng, 1988).

The family assignment of the new taxon from Socotra is closest to the Potamidae, because $S$. pseudocardisoma conforms to the definitions of the family Potamidae provided by Bott (1970), $\mathrm{Ng}$ (1988) and $\mathrm{Ng}$ and Naiyanetr (1993). Members of the Potamidae have the following characters: a frontal margin that is uninterrupted with no trace of a median triangle, a three-segmented mandibular palp with a simple (not bilobed) terminal segment, a triangular male abdomen, and a four-part gonopod with a clear demarcation between the terminal article and the subterminal segment.

Socotra pseudocardisoma can be distinguished from $P$. socotrensis (the other species of freshwater crab found on Socotra) by the characters listed above in the diagnosis. Additional characters include the large adult body size, and the habitat where the specimens were collected. For example, adult specimens of $S$. pseudocardisoma are considerably larger than adults of $P$. socotrensis (the largest adult specimen of $P$. socotrensis recorded by one of the authors (W.W.) had a cw of $39 \mathrm{~mm}$ ), and $S$. pseudocardisoma is found (so far) in limestone crevices in the limestone plateau of the higher elevations of the island, whereas $P$. socotrensis is found in streams, rivers and the more conventional freshwater habitats.

The large size of the specimens, together with their semi-terrestrial habits and their striking superficial resemblance to the land crab genus Cardisoma (Grapsoidea, Gecarcinidae), raises questions about a possible relationship of the new taxon with the gecarcinids. Indeed, Cardisoma carnifex is known to occur on the island (Forbes, 1904, Wranik, 1999). However, a number of characters (direct development from large egg to hatchling crab, a life cycle completed entirely in inland freshwater habitats, broad third maxillipeds whose ischia and meri meet vertically along their medial margins, a first gonopod with a long tapering terminal article, and male sexual ducts that open on the coxae of P5) clearly indicate that Socotra is a true freshwater crab (Potamoidea) rather than a land crab (Grapsoidea, Gecarcinidae).

No traces of freshwater crabs have been found on the other islands of the Socotra Archipelago (figure 5). Abd al Kuri is the second largest island $\left(216 \mathrm{~km}^{2} /\right.$ altitude $850 \mathrm{~m}$ ) with a landscape dominated by chains of low hills. The conditions for inland crabs on Abd al Kuri are even more extreme than on Socotra, because here there is little surface water, and what little water there is tends to be brackish. The other two islands of the Archipelago (Samha and Darsa, 'The Brothers') are both small, arid, flat-topped limestone plateaux with sheer sides. Most of Samha ( $45 \mathrm{~km}^{2} /$ altitude $779 \mathrm{~m}$ ) is barren with only a few freshwater depots, while the smaller island of Darsa $\left(10 \mathrm{~km}^{2} /\right.$ altitude $357 \mathrm{~m}$ ) has no available freshwater, and is uninhabited (sustaining little more than a large population of rats).

\section{Biogeographical considerations}

From a biogeographical viewpoint the island of Socotra is fascinating. The unique character of Socotra is due in part to its position near the junction between three of the world's major biogeographical regions (Afrotropical, Oriental and Palaearctic), and in part to its great age and long geological history. Socotra originally formed part of the African-Arabian tectonic plate, and was part of the 
fault block that separated from the African mainland in Tertiary times by the same series of dislocations that produced the Gulf of Aden. Today, the majority of the plants and animals of Socotra have closer affinities with those of Africa than with those of the Arabian Peninsula. This may be expected, given the present closer proximity of the Socotra Archipelago to Africa than to Arabia, and the more historically recent connections with Africa. The remaining species on Socotra whose closest relatives today are found further afield (for example in the Seychelles, which lie some $1600 \mathrm{~km}$ to the south) may represent the descendants of an ancient relict flora and fauna that has survived until today.

Indeed, the granitic mountains of the Haghir massif have remained above sea level for millions of years, possibly even since the Mesozoic (Uvarov and Popov, 1958). Kossmat (1907) characterized Socotra as one of the 'most isolated pieces of land' in the history of the earth. Gregory (1903), quoted the following observation by T. G. Bonney: 'the topmost peaks of the Hagghier Mountains were at no time wholly submerged ... in the Hagghier Hills, we have probably a fragment of a continental area of great antiquity and of a land surface which may have been an "arc of refuge" to a terrestrial fauna and flora from one of the very earliest periods in the world's history'.

The finding that the freshwater crabs of Socotra (Potamon and Socotra) show affinities with the Palaearctic freshwater crab family Potamidae, rather than with the Afrotropical Potamonautidae is somewhat unexpected on biogeographical grounds. Socotra lies well to the south of the present southern limit of the genus Potamon (and indeed all potamids) in the Middle eastern region (i.e. the northern part of the Arabian peninsula, and the Euphrates/Tigris basin). Socotra is much closer to Somalia than to the Arabian Peninsula, but the relatively few species of freshwater crabs found in Somalia are not closely related to the Socotran freshwater crabs. For example, the Somalian fauna consists of species of Potamonautes (Potamonautidae) and Deckenia (Deckeniidae) and the Potamidae are not found there or anywhere else in East Africa (Bott, 1955; Pretzmann, 1977; Cumberlidge, 1999).

The freshwater crabs of Socotra may be isolated and disjunct outliers of the main distributional range of the Potamidae. Alternatively, the unusual combination of characters (especially in the case of $S$. pseudocardisoma) may represent a taxonomic anomaly whose significance is not yet fully realized (Sternberg and Cumberlidge, in press). Whatever the case, Socotra's two endemic species of freshwater crabs, $S$. pseudocardisoma and $P$. socotrensis, are of extreme biogeographical and phylogenetic interest.

\section{Etymology}

The new genus has been named Socotra to recognize that this species is endemic to the island of Socotra. The species name, pseudocardisoma, refers to the physical resemblance, in body size, general appearance and land-living habits, between this species and the well-known land crab Cardisoma. The name pseudocardisoma is used as a noun in apposition.

\section{Acknowledgements}

W.W. was supported in part by the Global Environmental Facility (GEF) Socotra Biodiversity Project, while N.C. was supported in part by a Faculty Grant from Northern Michigan University, Marquette, Michigan, USA. The Ministry of 
Agriculture and with the Environmental Protection Council of the Republic of Yemen is acknowledged for setting up wildlife laws, a site protection system and environmental education activities such as the UNESCO fact-finding mission to Socotra at the end of 1993 . That mission examined the possibility of establishing a Biosphere Reserve on Socotra.

\section{References}

Alexander, D. and Miller, T., 1996, Saving the spectacular flora of Socotra, Plant Talk (The Botanical Information Company Ltd. Kingston), 7, 19-22.

Bотт, R., 1955, Die Süsswasserkrabben von Afrika (Crust., Decap.) und ihre Stammesgeschichte, Annales du Musée Royal du Congo, (Tervuren, Belgique) C, Zoologie, 1(3,3), 209-352.

BotT, R., 1965, Die Süßwasserkrabben von Madagaskar, Bulletin du Muséum national d'Histoire naturelle Paris, 37(2), 335-350.

Botr, R., 1970, Die Süßwasserkrabben von Europa, Asien, Australien und ihre Stammesgeschichte, Abhandlungen der Senckenbergischen Naturforschenden. Gesellschaft Deutsch, 526, 1-338.

Cumberlidge, N., 1999, The Freshwater Crabs of West Africa, Faune et Flore Tropicales, 34 (Paris: IRD), $382 \mathrm{pp}$.

Cumberlidge, N., Sternberg, R. V., Bills, I. R. and Martin, H. A., 1999, A revision of the genus Platythelphusa A. Milne-Edwards, 1887 from Lake Tanganyika, East Africa (Decapoda: Potamoidea: Platythelphusidae), Journal of Natural History, 33, 1487-1512.

DAI, A. Y., 1997, A revision of freshwater crabs of the genus Nanhaipotamon Bott, 1968 from China (Crustacea: Decapoda: Brachyura: Potamidae), Raffles Bulletin of Zoology, 45(2), 209-235.

DAl, A. Y. and TÜRKAY, M., 1997, Revision of the Chinese freshwater crabs previously placed in the genus Isolapotamon Bott, 1968 (Crustacea: Decapoda: Brachyura: Potamidae), Raffles Bulletin of Zoology, 45(2), 237-264.

DAI, A. Y., Zhou, X. M. and PENG, W. D., 1995, Eight new species of the genus Sinopotamon from Jiangxi Province, China (Crustacea, Decapoda, Brachyura, Potamidae), Beaufortia, 45(5), 61-76.

Davis, S. D., Heywood, V. H. and Hamilton. A. C., 1994, Centres of Plant Diversity. A Guide and Strategy for their Conservation. Vol. 1: Europe, Africa, Southwest Asia and the Middle East (WWF and IUCN), pp. 293-316.

Forbes, H. O., 1904, The Natural History of Socotra and Abd-el-Kuri. Crustaceans. 1. The Decapods of Socotra, pp. 211-214.

Gregory, J. W., 1903, Geology, in Forbes (ed.) The Natural History of Socotra and Abd-elKuri, pp. $575-581$.

Hilgendorf, F., 1883, Dans Taschenberg, Beitrage zur Fauna der Insel Sokotra, Zeitschrift für Naturwissenschaft Halle, 11(4), 171-173.

Kingdon, J., 1989, Island Africa (Princeton, NJ: Princeton University Press), p. 287.

Kossmat, F., 1907, Geologie der Inseln Sokotra, Semha und Abd El Kuri, Denkschreif Kais. Akademie Wissenschaft Wien, Mat.-Nat. Kl., 71, 1-62.

Mifs, B. and Zımmer, H., 1993, Die Vegetation der Insel Sokotra im Indischen Ozean, Natur und Museum, 123(9), 253-264.

Mifs, B., Bfhyl, F. E. and Ch. Printzen, C., 1995, Die Waldformationen der Insel Sokotra (Indischer Ozean), Natur und Museum, 125(4), 122-133.

Milne-EdWARIDS, A., 1887, Observations sur les crabes des eaux douces de l'Afrique, Annales des Sciences naturelles, Zoologie Paris, 4(7), 121-149.

NG, P. K. L., 1988, The Freshwater Crabs of Peninsular Malaysia and Singapore (Singapore: Department of Zoology, University of Singapore, Shing Lee Publishers Pte.), pp. 1-156.

NG, P. K. L. and Dudgeon, D., 1991, The Potamidae and Parathelphusidae (Crustacea: Decapoda: Brachyura) of Hong Kong, Invertebrate Taxonomy, 6, 741-768.

NG, P. K. L. and NAIYANETR, P., 1993, New and recently described freshwater crabs (Crustacea: Decapoda: Brachyura: Potamidae, Gecarcinucidae and Parathelphusidae) from Thailand, Zoologische Verhandelingen, 284, 1-117.

NG, P. K. L., Stevcic, Z. and Pretzmann, G., 1995, A revision of the family Deckeniidae 
Ortmann, 1897 (Crustacea: Decapoda: Brachyura: Potamoidea), with description of a new genus (Gecarcinucidae: Gecarcinucoidea) from the Seychelles, Indian Ocean, Journal of Natural History, 29, 581-600.

PretzmanN, G., 1962, Die mediterranen und vorderasiatischen Süßwasserkrabben (Potamiden), Annalen des Naturhistorischen Museums in Wien, 65, 205-240.

PretzmanN, G., 1963a, Über einige süd- und ostasiatische Potamoniden, Annalen des Naturhistorischen Museums in Wien, 66, 361-372.

PretzmanN, G., 1963b, Weiterer Bericht über die mediterranen und vorderasiatischen Potamiden, Annalen des Naturhistorischen Museums in Wien, 66, 373-380.

Pretzmann, G., 1966a, Potamiden (Crustacea Brachyura) aus Afghanistan, Annalen des Naturhistorischen Museums in Wien, 69, 297-298.

Pretzmann, G., 1966b, Süßwasserkrabben aus dem westlichen Himalayagebiet, Annalen des Naturhistorischen Museums in Wien, 69, 299-303.

PretzmanN, G., 1976, Ergebnisse einiger Sammelreisen nach Vorderasien. 6. Teil: Die Süßwasserkrabben Persiens, Annalen des Naturhistorischen Museums in Wien, 80, $457-472$.

PretzmanN, G., 1977, Über einige ostafrikanische Süßwasserkrabben, Monitore Zoologico Italiano, 10, 233 .

PretzmanN, G., 1983, Ergebnisse einiger Sammelreisen nach Vorderasien. 7. Die Süßwasserkrabben der Türkei, Annalen des Naturhistorischen Museums in Wien, 84B, 281-300.

SternberG, von R. and Cumberlidge, N., in press, Notes on the position of the true freshwater crabs within the brachyrhynchan Eubrachyura (Crustacea: Decapoda: Brachyura), Hydrobiologia.

Uvarov, B. P. and Popov, G. B., 1958, The saltatorial Orthoptera of Socotra, Linnean Society of Zoology, 43, 359-389.

WraniK, W., 1999, Sokotra, Mensch und Natur, Jemen Studien, 258. 